\title{
KEARIFAN PEMBANGUNAN BERBASIS SUMBER DAYA MANUSIA
}

\author{
Oleh: Suranto Aw \\ suranto@uny.ac.id
}

\section{Abstrak}

Program pembangunan merupakan salah satu altematif untuk mencapai peningkatan derajat kesejahteraan suatu bangsa. Diperlukan kemampuan untuk secara arif memilih strategi pembangunan yang mampu meningkatkan kesejahteraan dan keberdayaan masyarakat. Pilihan tersebut adalah pada kearifan pembangunan berbasis Sumber Daya Manusia (SDM), yakni program pembangunan yang dilaksanakan dengan mendasarkan din pada logika human centered development. Dengan pola keanifan pembangunan ini, berarti SDM ditempatkan sebagai kunci utama keberhasilan pembangunan. Dengan demikian, pembangunan yang dilaksanakan menekankan pada inovasi, penguasaan ilmu pengetahuan, keterampilan dan teknologi, serta peningkatan daya kreasi.

\section{Pendahuluan}

Pengalaman sejarah pembangunan di berbagai negara telah membuktikan bahwa Sumber Daya Manusia (SDM) merupakan faktor yang sangat penting peranannya. Kualitas SDM telah meningkatkan keberdayaan masya-rakat, sehingga pada gilirannya masyarakat mampu berperan aktif dalam pembangunan. Pesatnya pembangunan ekonomi di Jepang setelah negara ini mengalami kehancuran total pada Perang Dunia II, terutama karena memiliki SDM yang berkualitas memadai. Mirip seperti Jepang, dua negara lain di Asia, yakni Korea Selatan dan Taiwan, juga mengalami pertumbuh- an ekonomi dengan cepat karena didukung oleh faktor SDM. Sofian Effendi (1995: 1) mengatakan, "Keajaiban Korea" (Korean Miracle) dan "Keajaiban Taiwan" (Taiwan Miracle) dipandang sebagai human resource based karena pembangunan SDM dilaksanakan lebih dahulu dari pada pembangunan ekonomi.

Sejalan dengan kenyataan sejarah tersebut, Moejarto Tjokrowinoto (1996:) mengemuka-kan dua altematif "kearifan" yang dapat dipilin untuk dilaksanakan dalam proses pembangunan pada masa mendatang. Pertama, kearifan pembangunan berparadigma lama yang 
mendasarkan diri pada logika production centered development. Proses pembangunan diutamakan untuk mencapai peningkatan produksi. Kedua, kearifan pembangunan berbasis pada pengembangan kualitas SDM, ialah proses pembangunan yang mendasarkan pada logika human centered development. Kedua kearifan tersebut memang mendasarkan pada asumsi-asumsi yang berbeda. Kearifan pembangunan yang mendasarkan diri pada logika produksi, menempatkan pertumbuhan ekonomi sebagai fokus perhatian pembangunan, dan melihat modal serta efisiensi ekonomi sebagai determinan pertumbuhan utama. Kearifan pembangunan yang berbasis pada logika pengembangan kualitas SDM, menjadikan manusia sebagai fokus utama pembangunan, manusia adalah potensi awal sekaligus merupakan tujuan pembangunan.

Berdasarkan uraian atas dua pola kearifan pembangunan tersebut, pilihan kita adalah pada kearifan pembangunan yang kedua, yaitu yang menempatkan SDM sebagai kunci utama pembangunan. Dengan demikian proses pembangunan yang kita laksanakan harus menekankan pada inovasi dan peningkatan daya kreasi manusia yang mempunyai keberdayaan untuk tumbuh secara memadai, mampu mengatasi berbagai tekanan sosial dan persaingan ekonomi.
Dalam konteks kecenderungan persaingan yang makin meningkat pada era global dan pasar bebas dewasa ini, sangatlah tepat dikembangkan kearifan pembangunan dengan menitik-beratkan SDM. Tujuannya adalah agar negara dan bangsa ini dapat lebih berdaya dalam segala aspek kehidupan, agar dapat memainkan peranan sebagai subjek yang mandiri dalam interaksi global.

\section{Teori-teori Pembangunan Berba- sis SDM}

Dalam tataran teori, telah berkembang berbagai aliran pemikiran (paradigma) untuk menjelaskan pembangunan berbasis kualitas SDM. Teori achievement motivation yang dikemukakan oleh McClelland (1967) menegaskan bahwa sudah sewajamya SDM menjadi tumpuan harapan keberhasilan pembangunan. Negara yang berhasil membangun adalah negara yang mempunyai konsentrasi tinggi dari orang-orang yang memiliki achievement motivation ( $n-A c h)$. Dengan kata lain, salah satu dimensi kepribadian manusia yang harus dikembangkan adalah motivasi yang kuat untuk berprestasi di bidang kerja masing-masing serta mempunyai etos kerja yang baik.

Hagen (1978) sependapat dengan McCleliand tentang peranan faktor makro individual, yaitu kepribadian manusia sebagai determinan 
keberhasilan pembangunan suatu negara. Akan tetapi dia menunjuk secara lebih rinci aspek kepribadian SDM yang paling berperan dalam menentukan keberhasilan pembangunan. Menurut Hagen, aspekaspek kepribadian itu meliputi: (a) intelegensi dan energi; (b) orientasi nilai; (c) kognisi; (d) kebutuhan (needs).

Teori lain yang menjelaskan kecenderungan penempatan SDM sebagai modal utama pembangunan, dikemukakan oleh Cardoso. Menurut Soewarsono dan Alvin Y. So (1994), Cardoso merupakan tokoh utama yang mulai melakukan pembaruan teori dependensi, dan hasil pembaruan tersebut adalah berupa teori yang diberi nama teori dependensi baru. Garis besar teori yang dikemukakan oleh Cardoso adalah sebagai berikut:

Pertama, "ketergantungan" bukanlah teori untuk menjelaskan pola keterbelakangan, tetapi sebagai metode untuk menganalisis situasi konkret negara sedang berkembang.

Kedua, tidak seperti teori dependensi klasik yang sepenuhnya menuduh faktor ekstem sebagai penyebab utama terjadinya ketergantungan dan keterbelakang-an, Cardoso justru memberi perhatian kepada faktor intern. Kalau persoalan ketergantungan oleh teori dependensi klasik dianggap sebagai persoalan ekonomi, maka depen- densi baru melihatnya sebagai aspek kemanusiaan. Persoalan pembangunan yang ada di dunia ini tidak dapat dibatasi pada pembahasan industri substitusi impor, atau hanya sekedar memperdebatkan strategi pertumbuhan. Persoalan utamanya justru terletak pada ada atau tidaknya kesadaran dan kemampuan manusianya sebagai pelaku pembangunan. Oleh karena itu, menurut Cardoso, untuk meningkatkan keberhasilan pembangunan, yang perlu diperhatikan bukanlah pada faktor ekonomi dan sumber daya alam, tetapi pada faktor manusianya yang menjadi pengelola dan pengguna aspek ekonomi dan sumber daya alam tersebut. Kunci keberhasilan pembangunan tidak semata-mata terletak pada daya dukung sumber daya lingkungan, tetapi yang lebih penting ialah tersedianya penduduk suatu negara yang secara kualitas dapat diandalkan. Cardoso menyimpulkan bahwa kita dewasa ini harus lebih memperhatikan usaha-usaha pembangkitan gerakan kerakyatan, perjuangan kelas, perumusan kembali kepentingan politik rakyat, dan peningkatan kualitas SDM secara lebih luas dan dalam.

Teori tentang peranan sentral kepribadian SDM dalam pembangunan dan peningkatan keberdayaan masyarakat, juga dikemukakan oleh Park Chung Hee. IImuwan sekaligus negarawan Korea ini mengemukakan aspek-aspek 
yang membentuk tipe kualitas SDM sebagai berikut:

(a) Diligence, sikap rajin bekerja, dapat menunaikan pekerjaan dengan hasil yang memenuhi standar;

(b) Thrifty, sikap hemat yang timbul sebagai konsekuensi sikap diligence;

(c) Self-help, atau sikap mandiri. Konsep tentang arti penting kualitas SDM dalam pembangunan, dapat juga kita temukan pada teon kualitas manusia Indonesia seutuhnya, yaitu manusia yang berkeseimbangan dan selaras dalam hubungannya dengan Tuhan, dengan sesama manusia, dengan bangsabangsa lain, dan dengan alam lingkungan.

Konsep tentang manusia Indonesia seutuhnya ini terkesan masih sangat abstrak, sehingga muncul kerbagai penafsiran dan interpretasi operasional. Alwi Dahlan (1992: 9-10; membagi kualitas manusia Indonesia seutuhnya menjadi dua kategori karakteristik, yaitu kualitas fisik dan kualitas non-fisik. Kualitas fisik terdiri dari: (a) kesegaran jasmani, (b) kesehatan, (c) daya tahan fisik. Kualitas non fisik terdiri dan berbagai karakteristik, yaitu:

(a) Kualitas kepribadian (kecerdasan, kemandirian, kreativitas, ketahanan mental, keseimbangan antara emosi dan rasio. (b) Kualitas bermasyarakat, ialah keselarasan hubungan dengan sesama manusia.

(c) Kualitas berbangsa, yaitu tingkat kesadaran berbangsa dan bernegara, kesadaran bahwa martabat bangsa dan negaranya sama dengan martabat bangsa dan negara lain.

(d) Kualitas spiritual, ialah kualitas religiusitas dan moralitas.

(e) Wawasan lingkungan, kualitas yang diperlukan untuk mewujudkan pembangunan yang berkelanjutan.

(f) Kualitas kekaryaan, ialah kemampuan merujudkan aspirasi dan potensi diri dalam bentuk kerja nyata guna menghasilkan sesuatu dengan mutu sebaikbaiknya.

\section{Strategi Peningkatan Kualitas SDM}

Berbagai teori mengatakan bahwa ketersediaan SDM berkualitas akan memberikan sumbangan nyata terhadap keberhasilan pembangunan. Suatu jumlah penduduk dengan kualitas yang memadai diperlukan untuk mendukung proses pembangunan yang makin pesat. Untuk memenuhi harapan tersebut, kiranya perlu lebih digalakkan berbagai upaya nyata untuk mencapai peningkatan hualitas SDM.

Pengembangan derajat kemanusiaan selalu terkait dengan pengembangan kualitas, dan tergan- 
tung pada aspek apa yang dikembangkan, maka dikenali tiga aspek pengembangan manusia, sebagaimana diuraikan oleh Wuryadi (1993:

1) sebagai berikut :

1. Pengembangan kualitas manusia baik secara individual maupun dalam kesatuan sebagai masyarakat.

2. Pengembangan kualitas SDM yang terkait dengan berbagai fungsi manusia.

3. Pengembangan kualitas kehidupan manusia yang secara langsung atau tidak langsung mendukung berbagai fungsi kehidupan manusia, baik sebagai layanan maupun sebagai peluang.

Kata kunci untuk strategi meraih peningkatan kualitas SDM adalah proses pendidikan. Masyarakat yang memiliki tingkat pendidikan memadai cenderung memiliki kesempatan kontribusi yang lebih baik dalam pembangunan. Oleh karena itu proses pembangunan yang arif, haruslah mengutamakan terciptanya kesempatan masyarakat untuk memperoleh pendidikan yang cukup. Tujuan pembangunan tidak semata-mata mencapai peningkatan taraf ekonomi, tetapi lebih penting dari itu adalah upaya peningkatan taraf pendidikan.

Untuk merealisasikan peningkatan derajat pendidikan ini, perlu ditempuh program pemerataan pendidikan di kalangan masyarakat.
Secara operasional diperlukan berbagai strategi, yaitu: (a) sosialisasi wajib belajar; (b) menggali swadaya dan mendorong kesadaran masyarakat akan pentingnya pendidikan; (c) menggalang parti-sipasi anggota masyarakat berkemampuan ekonomi untuk membantu pembiayaan pendidikan keluarga tidak mampu; (d) monitoring dan evalıasi pelaksanakan program pendiaikan; (e) meningkatkan rasa kesadaran, tanggung jawab, dan kemampuan melalui perubahan sikap mental masyarakat agar memiliki semangat belajar dan berwirausaha, (f) memasyarakatkan teknologi tepat guna serta mempersiapkan tenaga kerja yang memiliki keterampilan profesional, (g) membina kesadaran, sikap dan perilaku masyarakat agar senantiasa mampu melaksanakan berbagai kegiatan konstruktif dengan tetap memperhatikan noma moral dan norma sosial yang berlaku.

Meningkatkan derajat pendidikan masyarakat merupakan modal yang sangat menentukan dalam usaha peningkatan kualitas SDM. Oleh karena itu proses pembangunan berbasis pada pengembangan kualitas SDM perlu diaktualisasikan melalui para pengambil keputusan, eksekutif, perencana, pemikir dan elit politik yang diharapkan dapat mengen-dalikan dan mengarahkan program-program pembangunan. Selanjutnya, kualitas SDM ini akan 
menjadi variabel penting dalam rangka pemberdayaan masyarakat menghadapi berbagai tekanan dan persaingan sebagai dampak dari datangnya era globalisasi. Jangan sampai penduduk indonesia yang sekarang ini berjumlah sekitar 210 juta jiwa hanya menjadi sasaran pasar bagi keuntungan negara lain. Jangan sampai penduduk Indonesia menjadi penonton yang tidak berdaya, baik itu akibat meluapnya barang buatan luar negeri, tenaga kerja asing yang mengisi berbagai jenis jabatan atau keahlian, maupun banjir informasi yang belum tentu sesuai dengan kebutuhan hidup serta nilai-nilai yang ada di Indonesia.

Namun demikian, investasi untuk pengembangan SDM melalui kegiatan pendidikan ini, hendaknya dilakukan dengan penuh perencanaan dan dengan memperhatikan kebutuhan kualifikasi tenaga keja pada masa yang akan datang. Tuntutan tersedianya tenaga ahli dan terampii di berbagai bidang pembangunan perlu diantisipasi sejak dini. Apabila hal ini tidak dilakukan, yang akan terjadi adalah ketidak-seinibangan antara permintaan dan penawaran SDM yang pada gilirannya akan menyebabkan ledakan jumlah penganggur terdidik. Dengan kata lain akan terjadi pemborosan yang besar, karena SDM terdidik yang telah dihasilkan dengan investasi yang mahal ternyata tidak dapat dimanfaatkan tenaga dan keahliannya.

\section{Kesimpulan}

Kearifan pembangunan berbasis pada pengembangan kualitas SDM, ialah sebuah pilihan proses pembangunan yang mendasarkan pada logika human centered development. Pola kearifan pembangunan berbasis SDM ini, menjadikan manusia sebagai fokus utama pembangunan, manusia adalah potensi awal sekaligus merupakan tujuan pembangunan. Pola kearifan seperti ini menjadi pilihan kita, dengan harapan agar masyarakat memperoleh peningkatan keterampilan, ilmu pengetahuan dan teknologi, serta peningkatan daya kreasi, sehingga pada gilirannya menjadi lebih berdaya dalam menghadapi berbagai tekanan dan persaingan global. Kearifan ini perlu lebih diaktualisasikan kembali melalui para pengambil keputusan, eksekutif, perencana pembangunan, maupun para elit politik, agar dapat terwujud sebagai program yang secara nyata dilaksanakan dalam kegiatan pembangunan bangsa dan negara.

\section{Daftar Pustaka}

Alwi Dahlan. 1992. Menjabarkan Kualitas dan Martabat Manusia. Yogyakarta: Gadjah Mada University Press. 
McClelland, David. 1977. The Achieving Society: New York: The Free Press.

Moejarto Tjokrowinoto. 1996. Pembangunan Dilema dan Tantangan. Yogyakarta: Pustaka Pelajar.

Suwarsono dan Alvin Y. So. 1994. Perubahan Sosial dan Pembangunan. Jakarta: LP3ES.

Wuryadi. 1997. Pengembangan Manusia dalam rangka Program Pembangunan Berkelanjutan. Majalah Cakrawala Pendidikan. Edisi Khusus.

\section{Biodata Penulis}

Suranto Aw, adalah staf pengajar pada Program Studi Pendidikan Administrasi Perkantoran Fakultas IImu Sosial Universitas Negeri Yogyakarta. Lulus Program studi PEP PPs UNY 1996 dan IImu Komunikasi PPS UNPAD. 